\title{
Arginase and Arginine Dysregulation in Asthma
}

\author{
Renée C. Benson, ${ }^{1}$ Karen A. Hardy, ${ }^{1}$ and Claudia R. Morris ${ }^{2}$ \\ ${ }^{1}$ Bay Area Pediatric Pulmonary Medical Corporation, Children's Hospital \& Research Center Oakland, Oakland, CA 94609, USA \\ ${ }^{2}$ Department of Emergency Medicine, Children's Hospital \& Research Center Oakland, Oakland, CA 94609, USA
}

Correspondence should be addressed to Claudia R. Morris, claudiamorris@comcast.net

Received 1 December 2010; Revised 7 February 2011; Accepted 10 February 2011

Academic Editor: Stephen P. Peters

Copyright ( 2011 Renée C. Benson et al. This is an open access article distributed under the Creative Commons Attribution License, which permits unrestricted use, distribution, and reproduction in any medium, provided the original work is properly cited.

In recent years, evidence has accumulated indicating that the enzyme arginase, which converts L-arginine into L-ornithine and urea, plays a key role in the pathogenesis of pulmonary disorders such as asthma through dysregulation of L-arginine metabolism and modulation of nitric oxide (NO) homeostasis. Allergic asthma is characterized by airway hyperresponsiveness, inflammation, and remodeling. Through substrate competition, arginase decreases bioavailability of L-arginine for nitric oxide synthase (NOS), thereby limiting NO production with subsequent effects on airway tone and inflammation. By decreasing Larginine bioavailability, arginase may also contribute to the uncoupling of NOS and the formation of the proinflammatory oxidant peroxynitrite in the airways. Finally, arginase may play a role in the development of chronic airway remodeling through formation of L-ornithine with downstream production of polyamines and L-proline, which are involved in processes of cellular proliferation and collagen deposition. Further research on modulation of arginase activity and L-arginine bioavailability may reveal promising novel therapeutic strategies for asthma.

\section{Introduction}

Since the identification of nitric oxide as a bioactive molecule involved in the pathogenesis of pulmonary disorders, much research has focused on the importance of the nitric oxide synthase pathway involving conversion of L-arginine to $\mathrm{NO}$ and L-citrulline. More recently, the arginase pathway involving catabolism of L-arginine to L-ornithine and urea has garnered attention for its potential role in arginine dysregulation and alteration of nitric oxide metabolism, with implications for the pathogenesis of airway diseases such as asthma.

\section{Asthma and Arginine Dysregulation}

Allergic asthma is a chronic obstructive disease of the airways characterized by airway hyperresponsiveness, inflammation, and remodeling. Inhalation of allergen immediately induces the early asthmatic reaction (EAR) which involves cross-linking of IgE by allergen, followed by activation of cells bearing IgE receptor (predominantly mast cells and basophils) with subsequent release of cytokines, proteases, and proinflammatory mediators such as histamine $[1,2]$. This rapid inflammatory cascade leads to vasodilation and mucosal edema, mucus secretion, and contraction of airway smooth muscle. The late asthmatic reaction (LAR) is an intense IgE-mediated inflammatory response dominated by infiltration of eosinophils and mononuclear cells that begins three to nine hours after allergen challenge and is correlated with intensity of associated bronchial hyperresponsiveness $[3,4]$. By $24-48$ hours, $\mathrm{T}_{\mathrm{H}} 2$ cells elaborating cytokines IL-4, IL-5, GM-CSF, and IL-13 can be found infiltrating the inflamed airway, leading to further IgE production, induction of vascular adhesion molecules, promotion of chemotaxis, and eosinophil and macrophage activation [2]. Ongoing exposure to environmental allergens contributes to chronic inflammation and may result in airway remodeling characterized by hypertrophy of submucosal gland mass, smooth muscle cell hyperplasia, and basement membrane thickening due to subepithelial deposition of collagen [1, 5]. Such remodeling may lead to progressive loss of lung function over time $[1,6,7]$. Recent evidence demonstrates 
that arginase may play a role in arginine dysregulation which contributes to the pathogenesis of asthma through effects on altered NO metabolism.

\section{Nitric Oxide Metabolism and Airway Function}

Nitric oxide (NO) has been well described in the literature as an important signaling molecule involved in regulation of many mammalian physiologic and pathophysiologic processes, particularly in the lung $[8,9]$. NO plays a role in regulation of both pulmonary vascular tone as well as airway bronchomotor tone through effects on relaxation of smooth muscle. In addition, NO participates in inflammation and host defense against infection via alterations in vascular permeability, changes in epithelial barrier function and repair, cytotoxicity, upregulation of ciliary motility, altered mucus secretion, and inflammatory cell infiltration $[10,11]$. These multiple functions of NO have been implicated in the pathogenesis of chronic inflammatory airway diseases such as asthma.

NO is produced by a family of nitric oxide synthases (NOSs) that metabolize L-arginine through the intermediate $\mathrm{N}$-hydroxy-L-arginine (NOHA) to form $\mathrm{NO}$ and Lcitrulline using oxygen and NADPH as cosubstrates. Three NOS mammalian isoenzymes have been identified with varying distributions and production of NO. Neuronal NOS (nNOS or NOS I) and endothelial (eNOS or NOS III) are constitutively expressed (cNOS) in airway epithelium, inhibitory nonadrenergic noncholinergic (iNANC) neurons, and airway vasculature endothelial cells. Their activity is regulated by intracellular calcium, with rapid onset of activity and production of small amounts of NO on the order of picomolar concentrations. Inducible NOS (iNOS or NOS II) is transcriptionally regulated by proinflammatory stimuli, with the ability to produce large amounts (nanomolar concentrations) of NO over hours [11,12].

iNOS is known to be upregulated in asthmatic lungs, and increased levels of exhaled NO are well described in asthma patients $[13,14]$. Supplemental oral or inhaled L-arginine increases exhaled NO in both normal and asthmatic subjects, indicating that the bioavailability of L-arginine for NOS determines NO production within the airways [15-17]. In guinea pig tracheal preparations, L-arginine has been shown to inhibit airway hyperresponsiveness to methacholine and to increase iNANC nerve-mediated airway smooth muscle relaxation via increased production of NOS-derived $\mathrm{NO}$ $[18,19]$. Conversely, inhibition of NOS-derived NO by $\mathrm{N}(\mathrm{G}-)$ nitro-L-arginine methyl ester (L-NAME) amplifies bronchoconstriction in guinea pigs [20].

\section{L-Arginine Metabolism Determines NO Production}

As the only substrate for NOS, L-arginine bioavailability plays a key role in determining NO production and is dependent on pathways of biosynthesis, cellular uptake, and catabolism by NOS and arginase. Biosynthesis of the semiessential amino acid occurs in a stepwise fashion. L-glutamine and L-proline are absorbed from the small intestine and converted to L-ornithine. L-citrulline is then synthesized from L-ornithine by ornithine carbamoyltransferase (OTC) and carbamoylphosphate synthetase 1 (CPS1) in hepatocytes as part of the urea cycle, as well as in the intestine. L-arginine is produced from L-citrulline by cytosolic enzymes argininosuccinate synthetase 1 (ASS1) and argininosuccinate lyase (ASL). When L-arginine is subsequently metabolized to NO via NOS, L-citrulline is again produced and can be used for recycling back to Larginine, which may be an important source of L-arginine during prolonged NO synthesis by iNOS [12].

The primary source of L-arginine for most cells is cellular uptake via the Na-independent cationic amino acid transporter (CAT) proteins of the $\mathrm{y}^{+}$-system. In particular, upregulation of CAT-2B has been associated with increased L-arginine uptake under conditions of iNOS induction stimulated by proinflammatory mediators lipopolysaccharide (LPS) and interferon- $\gamma($ IFN- $\gamma)$ [21-26]. Ablation of the CAT-2 gene is associated with impaired iNOS-mediated NO synthesis in macrophages and astrocytes, which implies an important role of CAT-2 in uptake of L-arginine substrate for iNOS $[27,28]$.

L-arginine uptake via the $\mathrm{y}^{+}$-system can be inhibited by other amino acids such as L-ornithine and L-lysine, as well as by polycations such as eosinophil-derived major basic protein (MBP) and poly-L-arginine $[21,29,30]$. MBP inhibition of L-arginine uptake was associated with decreased NO synthesis in rat alveolar macrophages and tracheal epithelial cells, most likely related to reduced L-arginine availability [24]. In addition, airway hyperresponsiveness to methacholine has been shown to increase in rats and guinea pigs after treatment with poly-L-arginine, related to attenuation of epithelial NO production. Treatment with combined poly-L-arginine and the antagonist polyanion heparin restored L-arginine uptake and NO production and reversed airway hyperresponsiveness [31-33].

\section{Arginase and Catabolism of L-Arginine}

More recently, focus has turned to the pathway of Larginine catabolism by arginase as important in regulating endogenous NO production, with implications for airway function in lung diseases such as asthma. Arginase is a urea cycle enzyme that catalyzes the hydrolysis of L-arginine to urea and L-ornithine. Both Arginase I and II isoforms are constitutively expressed in the airways; Arginase I is additionally located in the cytosol of hepatic cells, while arginase II is mitochondrial and extrahepatic [12, 34]. While the affinity $(\mathrm{Km})$ of L-arginine for arginase is in the low micromolar range compared to the low millimolar range for NOS, substrate competition does occur between arginase and NOS because the Vmax of arginase is 1000fold higher [35-37]. By competing for a common substrate, arginase reduces the bioavailability of L-arginine for NOS, therefore limiting NO production. Specific arginase inhibitor $\mathrm{N}$-hydroxy-nor-L-arginine (nor-NOHA) has been shown 
TABle 1: Pharmacologic enzyme inhibitors.

\begin{tabular}{lclc}
\hline Inhibitor & Specificity & Route & Reference \\
\hline L-NAME & Nonselective NOS & Oral & {$[20,42,43]$} \\
NOHA & Arginase & Inhaled & {$[39,44,45]$} \\
\multirow{2}{*}{ nor-NOHA } & Arginase & $\begin{array}{l}\text { Inhaled, } \\
\text { intraperitoneal }\end{array}$ & {$[19,38,42,46,47]$} \\
L-NMMA & Arginase & Inhaled & {$[48]$} \\
ABH & Arginase & Inhaled & {$[49]$} \\
BEC & Arginase & Oropharyngeal & aspiration \\
\hline
\end{tabular}

List of abbreviations: $\mathrm{N}$ ( G-) nitro-L-arginine methyl ester (L-NAME), nitric oxide synthase (NOS), N-hydroxy-L-arginine (NOHA), N-hydroxy-norL-arginine (nor-NOHA), $\mathrm{N}^{\mathrm{G}}$-monomethyl-L-arginine (L-NMMA), 2(S)amino-6-boronohexanoic acid (ABH), S-(2-boronoethyl)-l-cysteine (BEC).

to attenuate methacholine-induced constriction of guinea pig trachea and to increase iNANC-mediated relaxation of tracheal smooth muscle preparations, which is consistent with increased NO production through NOS under conditions of arginase inhibition [19,38] (see Table 1 for list of pharmacologic enzyme inhibitors). NOS can also inhibit arginase activity through NOHA, the intermediate in NO synthesis [39]. Arginase product L-ornithine may also play a role in regulating availability of $\mathrm{L}$-arginine to NOS through competitive inhibition of arginase [37, 40, 41] as well as inhibition of L-arginine uptake by CATs of the $\mathrm{y}^{+}$-system $[21,29,30]$. L-ornithine also serves as a substrate for ornithine decarboxylase (ODC), which synthesizes polyamines involved in promotion of cell growth and repair, and for ornithine aminotransferase (OAT), leading to formation of L-proline which is required for collagen synthesis [12].

\section{6. $T_{H} 1 / T_{H} 2$ Regulation of Arginase and iNOS in Asthma}

Allergic asthma is clearly a complicated inflammatory disease involving many different stages, cell types, cytokines, and mediators which remain incompletely understood. Depending on the stage, different inflammatory mediators are released from the various cell types, with implications for NOS/arginase activity and airway function. Mast cells and basophils are involved in the EAR and secrete histamine and TNF- $\alpha$. Eosinophils play an important role in the LAR and contribute to ongoing inflammation through secretion of cytotoxic major basic protein and eosinophilic cationic protein. $\mathrm{T}$ cells are also key players in the pathophysiology of asthma, with the $\mathrm{T}_{\mathrm{H}} 1 / \mathrm{T}_{\mathrm{H}} 2$ balance well described as being weighted towards the $\mathrm{T}_{\mathrm{H}} 2$ pathway. $\mathrm{T}_{\mathrm{H}} 1$ cells (which secrete IL- 2 , IFN- $\gamma$, and TNF- $\beta$ ) are involved in macrophage activation and cell-mediated immunity. $\mathrm{T}_{\mathrm{H}} 2$ cells (which secrete IL-4, IL-5, IL-10, and IL-13) are involved in mast cell and eosinophil activation, and humoral immunity $[2,51]$.

The balance of iNOS versus arginase activity and level of $\mathrm{NO}$ production in the airway may be related to the balance of $\mathrm{T}_{\mathrm{H}} 1 / \mathrm{T}_{\mathrm{H}} 2$ cytokines during the inflammatory cascade. Experimental models of asthma have demonstrated that iNOS is induced by proinflammatory $\mathrm{T}_{\mathrm{H}} 1$ cytokines released from mast cells (such as TNF- $\alpha$, IFN- $\gamma$, and IL-1) after allergen challenge and during the $\operatorname{LAR}[9,14,52,53]$. Arginase activity is induced (and iNOS suppressed) by $\mathrm{T}_{\mathrm{H}} 2$ cytokines IL-4 and IL-10 in murine macrophages, although IL-4 does not induce arginase in human macrophages unless combined with agents that increase cAMP [5456]. Arginase activity increases following challenge with allergens such as ovalbumin, Dermatophagoides farinae, and Aspergillus fumigatus in guinea pig tracheal preparations, and in mouse and rat models of allergic asthma [44, 57-61]. Gene expression studies have also shown induction of arginase I more than arginase II gene expression in mouse models of allergen-challenged lungs and $\mathrm{T}_{\mathrm{H}} 2$ cytokine-mediated lung inflammation [59, 62-65].

\section{Altered NO Metabolism and Airway Hyperresponsiveness}

In asthmatic patients as well as experimental models of asthma, increased NO production occurs in the airways related to upregulation of iNOS by proinflammatory cytokines after allergen challenge and during the LAR $[9,14,52,53]$. This upregulation of iNOS in airway epithelial cells and inflammatory cells is associated with airway eosinophilia, airway hyperresponsiveness (AHR), and increased NO in exhaled air $[9,16,66-70]$. Antiinflammatory treatment with corticosteroids reduces all of these markers [71, 72]. The increased production of NO may actually be a protective mechanism to maintain airway tone in the setting of inflammatory changes. Studies of iNOS knockout mice have demonstrated increased airway inflammation and AHR compared to wild-type mice [46], whereas mice that overexpress iNOS demonstrate increased exhaled $\mathrm{NO}$ and decreased AHR without airway inflammation [73].

Airway inflammation in asthma may not be the result of increased NO production itself, but rather due to the formation of the proinflammatory oxidant peroxynitrite from reaction of NO with superoxide anions in the airway. Peroxynitrite activates eosinophils, increases MUC5AC expression, increases microvascular permeability, induces airway epithelial damage, and augments airway smooth muscle contraction [74-77]. Airway epithelial cells and inflammatory cells from bronchial biopsies of asthmatics as well as allergen-challenged guinea pigs demonstrate increased nitrotyrosine immunostaining (a marker for peroxynitrite nitration of protein tyrosine), which is also correlated with increased exhaled NO, iNOS expression, AHR, and eosinophilic inflammation $[75,78,79]$. The AHR observed after allergen challenge and the LAR may be the result of increased peroxynitrite formation $[74,80]$.

\section{Arginine Dysregulation Contributes to Airway Hyperresponsiveness}

In contrast to the increased $\mathrm{NO}$ production seen during the LAR, the increased AHR seen after the EAR may 
TABLE 2: Altered nitric oxide metabolism in allergic asthma.

\begin{tabular}{lccccc}
\hline & \multicolumn{5}{c}{ Stage of allergic asthma* } \\
& EAR & LAR & AHR & Inflammation & Remodeling \\
\hline NO & $\downarrow$ & $\uparrow$ & $\uparrow$ & $\uparrow$ & $\downarrow ?$ \\
cNOS & $\downarrow$ & $\leftrightarrow$ & $\leftrightarrow$ & $\leftrightarrow$ & $?$ \\
iNOS & $\leftrightarrow$ & $\uparrow$ & $\uparrow$ & $\uparrow$ & $?$ \\
Arginase & $\uparrow$ & $\uparrow$ & $\uparrow$ & $?$ & $\uparrow ?$ \\
\hline
\end{tabular}

${ }^{*}$ Production of nitric oxide (NO) during different stages of asthma is related to the balance of NOS (nitric oxide synthase) and arginase activity. During the early asthmatic reaction (EAR), increased arginase activity leads to deficiency of L-arginine substrate for cNOS (constitutive NOS), thereby decreasing NO production. iNOS (inducible NOS) is upregulated during the late asthmatic reaction (LAR) leading to increased NO production, at the same time as arginase activity increases, and airway hyperresponsiveness (AHR) increases. The availability of L-arginine substrate for both NOS and arginase may drive reactions and can contribute to proinflammatory peroxynitrite formation under low L-arginine conditions. Elevated NO and iNOS are clearly associated with chronic allergic inflammation, but the role of arginase in this stage is less apparent. At this time, little is known about the roles of NO, NOS, and arginase during airway remodeling in asthma, and further studies are needed to elucidate these pathways.

paradoxically involve NO deficiency within the airways related to reduced bioavailability of L-arginine to both $\mathrm{cNOS}$ and iNOS.

In guinea pig models of acute allergic asthma, exhaled NO drops during the allergen-induced EAR, and iNOS is not detected until the LAR, indicating that decreased cNOS production of NO may contribute to subsequent AHR [67, 81-83]. Table 2 describes the relative activity of NOS and arginase with respect to the various stages of allergic asthma. In patients with severe asthma and evidence of AHR treated with corticosteroids, inhaled NOS inhibitor $\mathrm{N}^{\mathrm{G}}$-monomethyl-L-arginine (L-NMMA) failed to potentiate bradykinin-mediated bronchoconstriction. The authors concluded that this effect reflected corticosteroid downregulation of iNOS, with reduced cNOS-derived NO leading to failure of bronchoprotection and increased AHR [48].

Reduced L-arginine bioavailability to cNOS may be responsible for the NO deficiency seen after the allergeninduced EAR, as animal studies supplementing L-arginine have shown decreased airway hyperresponsiveness after the allergen-induced EAR. L-arginine supplementation reduced the AHR to methacholine and increased iNANC nervemediated airway smooth muscle relaxation in guinea pig tracheal preparations, as well as attenuating the AHR to histamine after the EAR in vivo in guinea pigs $[18,47,49]$. Low L-arginine conditions may also lead to increased production of peroxynitrite after the LAR by uncoupling iNOS, allowing it to produce superoxide anions via its reductase domain, which react with NO to form peroxynitrite [84]. Increasing L-arginine availability increases NO production and decreases superoxide and peroxynitrite production in macrophages [85].

\section{Arginase and Airway Hyperresponsiveness}

As arginase plays a role in regulating bioavailability of L-arginine for NOS by competitive consumption of the substrate, increased arginase activity may be responsible for the AHR after the EAR and LAR. In allergen-challenged mice, arginase activity is increased in the airways at the same time as L-arginine and L-citrulline levels are decreased [86]. Arginase's role in allergen-induced AHR is demonstrated by animal studies involving inhibition of both arginase and NOS. Perfused guinea pig tracheal rings treated with specific arginase inhibitor nor-NOHA demonstrated normalization of allergen-induced AHR, and this effect was prevented by coincubation with NOS inhibitor L-NAME, indicating that arginase leads to AHR by decreasing cNOS-derived NO production [42]. iNANC nerve-mediated NO production and smooth muscle relaxation is also restored after the EAR by treatment with nor-NOHA, to a similar level also seen with L-arginine supplementation [47]. Another specific arginase inhibitor (2 (S-) amino-6-boronohexanoic acid or $\mathrm{ABH}$ ) not only reverses AHR after the EAR and LAR following histamine challenge in a guinea pig model of acute allergic asthma but also prevents AHR when delivered 30 minutes prior to the histamine challenge, most likely related to increased NO production [49]. Similarly, intraperitoneal treatment with nor-NOHA prior to repeated allergen challenge reduced AHR to methacholine in mice [46].

As noted above, arginase competition for L-arginine may also contribute to the LAR by increasing peroxynitrite formation through promotion of uncoupling of iNOS under low Larginine conditions, thereby resulting in the AHR seen after the LAR $[57,87]$. Evidence for this relationship comes from the lungs of $D$. farinae-challenged mice which demonstrate increased nitrotyrosine staining and concomitant increased expression of arginase and iNOS [44].

Studies in human asthma confirm the importance of arginase in the pathogenesis of experimental asthma. While increased arginase activity in the sputum of asthmatic patients was documented as early as 1980 [88], its role in the pathophysiology of asthma was not further elucidated until decades later. Increased arginase I activity, mRNA, and protein expression have now been demonstrated in inflammatory cells and airway epithelium from bronchial biopsies, as well as bronchoalveolar lavage samples from asthmatic patients [58, 59]. Single nucleotide polymorphisms (SNPs) in both arginase I and arginase II have been associated with atopy, while SNPs in arginase II were associated with increased risk of childhood asthma [89]. Increased arginase activity has also been demonstrated in the serum of asthmatic children experiencing an exacerbation, at the same time as plasma L-arginine levels and the arginine/ornithine ratio (a biomarker that inversely correlates to arginase activity) were reduced. Improvement in asthma symptoms corresponded temporally with reduction of arginase activity and increase in plasma L-arginine levels and the arginine/ornithine ratio [90]. The lung function of severe asthmatics (FEV1 and FEV1/FVC) correlates directly with L-arginine bioavailability, and inversely with serum arginase activity, indicating that serum arginase activity reduces circulating L-arginine levels which contribute to NO deficiency within the airways [91]. 


\section{Arginase and Airway Inflammation}

Airway inflammation is a key problem in asthma and remains the main therapeutic target for treatment of the disease. Arginase expression has been documented in inflammatory cells of both animal models and humans, but models of arginase inhibition have not yet revealed a consistent effect on inflammatory pathways. Human polymorphonuclear cells and eosinophils constitutively express arginase I, which is located in azurophilic granules and upon release plays a role in regulation of L-arginine concentration, suppression of activation of T-lymphocytes and NK cells, and antimicrobial activity [92]. Arginase is highly expressed in M2 alternatively activated macrophages which are stimulated by IL- 4 and IL13 cytokines produced by CD4+ $\mathrm{T}_{\mathrm{H}} 2$ cells, $\mathrm{CD} 8+\mathrm{T}$ cells, NK cells, basophils, mast cells, and eosinophils $[93,94]$. In contrast, classical activation of macrophages for cytotoxic killing involves a $T_{H} 1$ inflammatory pathway in which arginase may play a detrimental role of limiting NO production. Arginase from alternatively activated macrophages, however, may play a role in resolution of inflammation and wound healing via a shift towards synthesis of proline and polyamines instead of NO production [94-96].

Contradictory studies of arginase inhibition have reported enhancement, attenuation, and no effect on inflammation in animal models $[46,49,50,97]$ and may reflect issues specific to animal models of asthma in general that often limit our understanding and treatment of asthma [98]. Since chronic asthma is a disease unique to humans, the fact that mice do not have asthma may contribute to the conflicting reports that make the mechanistic translation to human disease more of a challenge. Further studies are needed to clarify these effects and their implications in man. In mice sensitized to ovalbumin, arginase inhibitor S-(2boronoethyl)-l-cysteine (BEC) increased peribronchiolar and perivascular inflammation associated with increased S-nitrosothiols and 3-nitrotyrosine but did not change allergen-induced increases in differential cell counts or cytokine levels in BAL samples [50]. Unfortunately, the role of low arginine bioavailability and NOS uncoupling as a plausible contributing factor to excess superoxide production in this model is unknown. In another study, arginase inhibitor nor-NOHA administration prior to ovalbumin challenge in mice decreased total cell count in BAL samples by $65 \%$ felt to be related to increased NO production, whereas iNOS-knockout mice had an increased inflammatory response to the ovalbumin challenge [46]. $\mathrm{ABH}$ administration to guinea pigs similarly inhibited allergen-induced increases in BAL inflammatory cells (eosinophils, macrophages, and total cells) by $50 \%$ [49]. Finally, in chimeric mice with arginase $\mathrm{I}^{-/-}$bone marrow, no change was seen in basal or allergen-induced inflammatory cell infiltration or BAL differential cell counts, indicating that at least bone marrow-derived arginase I is not required for development of lung inflammation in the mouse model [97].

\section{Arginase and Chronic Airway Remodeling}

Airway remodeling can be seen in asthma as a result of chronic airway inflammation, and prevention of this complication is a major goal for treatment. Eosinophilia, TGF- $\beta$, and IL-13 are postulated to play a role in the process of airway remodeling [99]. Arginase may also participate in the development of airway fibrosis via the pathway of L-ornithine production, with subsequent synthesis of polyamines (involved in promotion of cell growth and proliferation) and L-proline (involved in collagen synthesis). Indeed, alternatively activated macrophages expressing arginase I have been implicated in diseases such as idiopathic pulmonary fibrosis [100]. Mouse models of lung fibrosis reveal a dose-dependent correlation between profibrotic factor TGF- $\beta$ and arginase activity in lung tissue and fibroblasts [101]. In mouse models of bleomycin-induced pulmonary fibrosis, increased expression of arginase I and II and decreased L-arginine availability are associated with increased collagen I expression [45]. Inhibition of arginase by nonspecific inhibitor NOHA decreases TGF- $\beta 1$-stimulated collagen deposition [44, 45]. Another mouse model of lung fibrosis investigated the role of TGF- $\beta$ upregulation using transgenic mice expressing human TGF- $\beta$ under the control of the Clara cell promoter. Following treatment with doxycycline, IL-13 was upregulated, macrophages were activated via the alternative pathway, arginase I and II expression and arginase activity were augmented, and pulmonary fibrosis increased [102]. Taken together, arginase seems to play a role in the fibrotic pathway induced by TGF- $\beta$ by metabolism of L-arginine to L-ornithine, leading to downstream production of proline and polyamines, and finally resulting in collagen deposition and fibrosis.

Arginase may also play a role in airway remodeling and fibrosis by decreasing NO production through competition for L-arginine, thereby reducing antifibrotic and antismooth muscle proliferation effects of NO. Antifibrotic properties of NO are demonstrated in studies of increased allergeninduced collagen deposition in the airways of guinea pigs after treatment with NOS inhibitor L-NAME and increased collagen deposition in allergen-challenged iNOS knockout mice compared to wild type $[43,104]$. NO limits proliferation of human and guinea pig cultured airway smooth muscle cells by inhibiting cell cycle progression [105-108]. Finally, arginase may itself contribute to smooth muscle proliferation via synthesis of polyamines and subsequent stimulation of cell proliferation [109-112].

\section{Arginase and Novel Therapeutic Targets for Asthma}

Increased understanding of the role of arginase in the pathogenesis of asthma naturally leads to consideration of novel therapeutic targets for treatment. As noted above, animal models of specific arginase inhibition have demonstrated prevention or reversal of airway hyperresponsiveness associated with allergen challenge, and therefore further development and study of inhaled arginase inhibitors may be a promising area of research. 


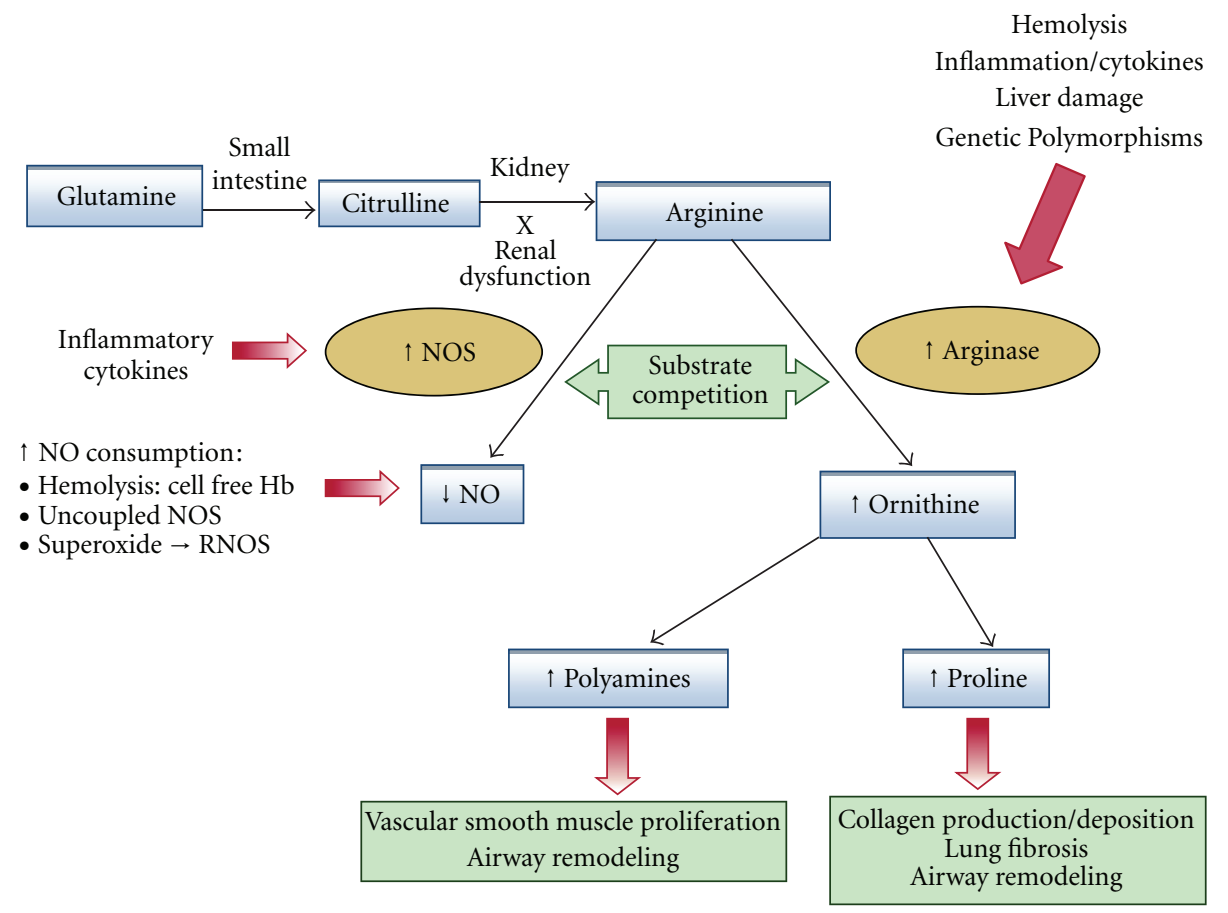

FIGURE 1: Altered arginine metabolism in hemolysis: a path to pulmonary dysfunction. Dietary glutamine serves as a precursor for the de novo production of arginine through the citrulline-arginine pathway. Arginine is synthesized endogenously from citrulline primarily via the intestinal-renal axis. Arginase and nitric oxide synthase (NOS) compete for arginine, their common substrate. In sickle cell disease (SCD) and thalassemia, bioavailability of arginine and $\mathrm{NO}$ are decreased by several mechanisms linked to hemolysis. The release of erythrocyte arginase during hemolysis increases plasma arginase levels and shifts arginine metabolism towards ornithine production, limiting the amount of substrate available for NO production. The bioavailability of arginine is further diminished by increased ornithine levels because ornithine and arginine compete for the same transporter system for cellular uptake. Despite an increase in NOS, NO bioavailability is low due to low substrate availability, NO scavenging by cell-free hemoglobin released during hemolysis, and through reactions with free radicals such as superoxide and other reactive NO species. Superoxide is elevated in SCD due to low superoxide dismutase activity, high xanthine oxidase activity, and potentially as a result of uncoupled NOS in an environment of low arginine and/or tetrahydrobiopterin concentration or insufficient NADPH. Endothelial dysfunction resulting from NO depletion and increased levels of the downstream products of ornithine metabolism (polyamines and proline) likely contribute to the pathogenesis of lung injury, pulmonary hypertension, and asthma in SCD. This model has implications for all hemolytic processes as well as pulmonary diseases associated with excess arginase production. This novel disease paradigm is now recognized as an important mechanism in the pathophysiology of SCD and thalassemia. Abnormal arginase activity emerges as a recurrent theme in the pathogenesis of a growing number of diverse pulmonary disorders. Regardless of the initiating trigger, excess arginase activity represents a common pathway in the pathogenesis of asthma and pulmonary hypertension, reproduced with permission from the American Society of Hematology [103].

Restoration of L-arginine bioavailability to NOS through exogenous supplementation of L-arginine is another potential therapeutic target, although a great deal of orally administered L-arginine is metabolized to urea in the liver. Its utility may be further limited by excess arginase found in seurm during an acute asthma exacerbation in humans [90], skewing metabolism away from NO towards ornithine and its downstream metabolites, proline, and polyamines. Combination therapy utilizing L-arginine with an arginase inhibitor may circumvent this issue. Alternatively, L-citrulline or L-glutamine (converted to citrulline by the enterocytes) could be administered as a prodrug for Larginine, as citrulline is converted in the kidney to arginine through the "intestinal-renal axis" [113], thus bypassing liver metabolism by arginase. Interestingly, citrulline supplementation in a pilot phase II clinical trial in sickle cell patients resulted in an increase in plasma L-arginine levels [114].
Preliminary results of pharmacokinetic studies using oral Lglutamine have also demonstrated improvement in global arginine bioavailability in patients with SCD and pulmonary hypertension [115].

\section{Sickle Cell Disease: A Unique Asthma Paradigm}

Sickle cell disease (SCD) is an inherited hemoglobinopathy that causes a chronic hemolytic anemia. Asthma is a common comorbidity in SCD with a reported prevalence of $30-$ $70 \%$ [116-124]. The high frequency of asthma in this population cannot be attributed to genetic predisposition alone and likely reflects in part the contribution of overlapping mechanisms shared between these otherwise distinct disorders $[90,125]$. There is accumulating evidence that 
dysregulated arginine metabolism and in particular elevated arginase activity contributes to pulmonary complications in hemolytic disorders that include SCD and the thalassemia syndromes [103, 126-132]. As summarized in this review, derangements of arginine metabolism are also emerging as newly appreciated mechanism in both asthma [57, 90, 91, 133, 134] and pulmonary hypertension independent of SCD [135-139] (Figure 1). Patients with SCD may potentially be at risk for an "asthma-like" condition triggered or worsened by hemolysis-driven release of erythrocyte arginase and low nitric oxide bioavailability [125, 127], in addition to classic familial asthma [140]. An abnormal methacholine challenge and airway hyperreactivity has been documented in up to $78 \%$ of children with SCD tested [141-143]. Of interest, a recent study of 99 children with SCD found few typical features of asthma associated with a positive methacholine challenge. Although methacholine responsiveness was correlated to a higher serum IgE, there was no relationship between responsiveness and $\mathrm{FEV}_{1} \%$ predicted, $\mathrm{FEV}_{1} / \mathrm{FVC} \%$ predicted, bronchodilatory reactivity, eNO, allergy skin tests, or eosinophil count. However, increased methacholine responsiveness was strongly correlated to higher plasma LDH [143], a biomarker of hemolysis [144] robustly associated with erythrocyte-released plasma arginase concentration $[127,144]$. Given the association of asthma with inflammation, oxidative stress and hypoxemia, factors known to contribute to a vasculopathy in SCD, and the consequences of these factors on sickle erythrocytes, comorbid asthma would likely contribute to a vicious cycle of sickling and subsequent complications of SCD [125]. Indeed, a growing body of evidence links asthma to complications in SCD, including acute chest syndrome [145], stroke [120], pulmonary hypertension [124], and early mortality [123]. Whether this is true "asthma" by the conventional definition or an "asthma-like" co-morbidity specific to SCD remains unknown but is a current topic of interest $[125,126,140$, 143]. It is likely that dysregulated arginine metabolism and excess production of proline and polyamines contribute to many forms of abnormal pulmonary function in SCD and other hemoglobinopathies [125]. In fact, we may learn a great deal about the asthma paradigm itself from the "asthma-like" condition that frequently develops in patients with SCD.

\section{Conclusion}

Recent research has revealed mounting evidence for a causal role for arginase in the development of airway hyperresponsiveness, airway inflammation, and chronic airway remodeling which comprise allergic asthma. The effects of arginase on nitric oxide metabolism are related to its competitive consumption of L-arginine, leading to decreased NO production and increased peroxynitrite formation. In addition, the arginase by-product L-ornithine contributes to synthesis of polyamines and L-proline which play a role in pathways of fibrosis by contributing to cellular proliferation and collagen deposition. Further research is warranted to investigate arginase and arginine as potential new therapeutic targets for treatment of asthma.

\section{Conflict of Interests}

C. R. Morris, MD, is the inventor or coinventor of several Children's Hospital \& Research Center Oakland patents/patent applications for biomarkers and novel therapeutics that target global arginine bioavailability; has received research support from Merck; served on scientific advisory committees for Merck and Icagen; received an educational stipend from INO Therapeutics; has been a consultant for Biomarin, Gilead Sciences, Inc, and the Clinical Advisors Independent Consulting Group. K. A. Hardy, $\mathrm{MD}$, is the investigator for several multicenter trials for cystic fibrosis (CF) with funding from the CF Foundation, Inspire pharmaceuticals, and the CDC. She is a member of the speaker bureaus for MedImmune, Glaxo Kline Smith, and Merck. She serves on the asthma advisory boards for Children's First Medical Group and Brown and Toland Medical Group.

\section{Acknowledgment}

This research was supported by the FDA Grant 1R01FD003531-02 (to C. R. Morris).

\section{References}

[1] J. Bousquet, P. K. Jeffery, W. W. Busse, M. Johnson, and A. M. Vignola, "Asthma: from bronchoconstriction to airways inflammation and remodeling," American Journal of Respiratory and Critical Care Medicine, vol. 161, no. 5, pp. 17201745, 2000.

[2] D. Y. M. Leung, "Molecular basis of allergic diseases," Molecular Genetics and Metabolism, vol. 63, no. 3, pp. 157167, 1998.

[3] A. Cartier, N. C. Thomson, and P. A. Frith, "Allergeninduced increase in bronchial responsiveness to histamine: relationship to the late asthmatic response and change in airway caliber," Journal of Allergy and Clinical Immunology, vol. 70, no. 3, pp. 170-177, 1982.

[4] D. W. Cockcroft and B. E. Davis, "Mechanisms of airway hyperresponsiveness," Journal of Allergy and Clinical Immunology, vol. 118, no. 3, pp. 551-559, 2006.

[5] C. M. Kercsmar, "Wheezing in Older Children: Asthma," in Kendig's Disorders of the Respiratory Tract in Children, V. Chernick et al., Ed., Saunders Elsevier, Philadelphia, Pa, USA, 2006.

[6] P. K. Jeffery, "Remodeling in asthma and chronic obstructive lung disease," American journal of respiratory and critical care medicine, vol. 164, no. 10, pp. S28-S38, 2001.

[7] D. S. Postma and W. Timens, "Remodeling in asthma and chronic obstructive pulmonary disease," Proceedings of the American Thoracic Society, vol. 3, no. 5, pp. 434-439, 2006.

[8] S. Moncada, R. M. J. Palmer, and E. A. Higgs, "Nitric oxide: physiology, pathophysiology, and pharmacology," Pharmacological Reviews, vol. 43, no. 2, pp. 109-142, 1991.

[9] F. L. M. Ricciardolo, P. J. Sterk, B. Gaston, and G. Folkerts, "Nitric oxide in health and disease of the respiratory system," Physiological Reviews, vol. 84, no. 3, pp. 731-765, 2004.

[10] T. J. Moraes, "Arginase and respiratory viral infections," The Open Nitric Oxide Journal, vol. 2, pp. 64-68, 2010. 
[11] A. E. Redington, "Modulation of nitric oxide pathways: therapeutic potential in asthma and chronic obstructive pulmonary disease," European Journal of Pharmacology, vol. 533, no. 1-3, pp. 263-276, 2006.

[12] K. Racke and M. Warnken, "L-arginine metabolic pathways," The Open Nitric Oxide Journal, vol. 2, pp. 9-19, 2010.

[13] G. Folkerts, J. Kloek, R. B. R. Muijsers, and F. P. Nijkamp, "Reactive nitrogen and oxygen species in airway inflammation," European Journal of Pharmacology, vol. 429, no. 1-3, pp. 251-262, 2001.

[14] Q. Hamid, D. R. Springall, V. Riveros-Moreno et al., "Induction of nitric oxide synthase in asthma," Lancet, vol. 342, no. 8886-8887, pp. 1510-1513, 1993.

[15] S. A. Kharitonov, G. Lubec, B. Lubec, M. Hjelm, and P. J. Barnes, "L-Arginine increases exhaled nitric oxide in normal human subjects," Clinical Science, vol. 88, no. 2, pp. 135-139, 1995.

[16] S. A. Kharitonov, D. Yates, R. A. Robbins, R. Logan-Sinclair, E. A. Shinebourne, and P. J. Barnes, "Increased nitric oxide in exhaled air of asthmatic patients," Lancet, vol. 343, no. 8890, pp. 133-135, 1994.

[17] M. A. Sapienza, S. A. Kharitonov, I. Horvath, K. F. Chung, and P. J. Barnes, "Effect of inhaled L-arginine on exhaled nitric oxide in normal and asthmatic subjects," Thorax, vol. 53, no. 3, pp. 172-175, 1998.

[18] J. De Boer, M. Duyvendak, F. E. Schuurman, F. M.H. Pouw, J. Zaagsma, and H. Meurs, "Role of L-arginine in the deficiency of nitric oxide and airway hyperreactivity after the allergeninduced early asthmatic reaction in guinea-pigs," British Journal of Pharmacology, vol. 128, no. 5, pp. 1114-1120, 1999.

[19] H. Maarsingh, M. A. Tio, J. Zaagsma, and H. Meurs, "Arginase attenuates inhibitory nonadrenergic noncholinergic nerve-induced nitric oxide generation and airway smooth muscle relaxation," Respiratory Research, vol. 6, article 23, 2005.

[20] C. M. Prado, E. A. Leick-Maldonado, L. Yano et al., "Effects of nitric oxide synthases in chronic allergic airway inflammation and remodeling," American Journal of Respiratory Cell and Molecular Biology, vol. 35, no. 4, pp. 457-465, 2006.

[21] M. D. Messeri Dreißig, R. Hammermann, J. Mössner, M. Göthert, and K. Racké, "In rat alveolar macrophages lipopolysaccharides exert divergent effects on the transport of the cationic amino acids L-arginine and L-ornithine," Naunyn-Schmiedeberg's Archives of Pharmacology, vol. 361, no. 6, pp. 621-628, 2000.

[22] R. G. Bogle, A. R. Baydoun, J. D. Pearson, S. Moncada, and G. E. Mann, "L-Arginine transport is increased in macrophages generating nitric oxide," Biochemical Journal, vol. 284, no. 1, pp. 15-18, 1992.

[23] H. Sato, M. Fujiwara, and S. Bannai, "Effect of lipopolysaccharide on transport and metabolism of arginine in mouse peritoneal macrophages," Journal of Leukocyte Biology, vol. 52, no. 2, pp. 161-164, 1992.

[24] R. Hammermann, J. Hirschmann, C. Hey et al., "Cationic proteins inhibit L-arginine uptake in rat alveolar macrophages and tracheal epithelial cells: implications for nitric oxide synthesis," American Journal of Respiratory Cell and Molecular Biology, vol. 21, no. 2, pp. 155-162, 1999.

[25] R. Hammermann, M. D. M. Dreißig, J. Mössner et al., "Nuclear factor- $\kappa \mathrm{B}$ mediates simultaneous induction of inducible nitric-oxide synthase and up-regulation of the cationic amino acid transporter CAT-2B in rat alveolar macrophages," Molecular Pharmacology, vol. 58, no. 6, pp. 1294-1302, 2000.
[26] R. Hammermann, C. Stichnote, E. I. Closs, H. Nawrath, and K. Racké, "Inhibition of nitric oxide synthase abrogates lipopolysaccharides-induced up-regulation of L-arginine uptake in rat alveolar macrophages," British Journal of Pharmacology, vol. 133, no. 3, pp. 379-386, 2001.

[27] B. Nicholson, C. K. Manner, J. Kleeman, and C. L. MacLeod, "Sustained nitric oxide production in macrophages requires the arginine transporter CAT2," Journal of Biological Chemistry, vol. 276, no. 19, pp. 15881-15885, 2001.

[28] C. K. Manner, B. Nicholson, and C. L. MacLeod, "CAT2 arginine transporter deficiency significantly reduces iNOSmediated NO production in astrocytes," Journal of Neurochemistry, vol. 85, no. 2, pp. 476-482, 2003.

[29] R. Devés and C. A. R. Boyd, "Transporters for cationic amino acids in animal cells: discovery, structure, and function," Physiological Reviews, vol. 78, no. 2, pp. 487-545, 1998.

[30] R. M. Schapira, J. H. Wiessner, J. F. Morrisey, U. A. Almagro, and L. D. Nelin, "L-arginine uptake and metabolism by lung macrophages and neutrophils following intratracheal instillation of silica in vivo," American Journal of Respiratory Cell and Molecular Biology, vol. 19, no. 2, pp. 308-315, 1998.

[31] D. A. Uchida, S. J. Ackerman, A. J. Coyle et al., "The effect of human eosinophil granule major basic protein on airway responsiveness in the rat in vivo: a comparison with polycations," American Review of Respiratory Disease, vol. 147, no. 4, pp. 982-988, 1993.

[32] H. Meurs, F. E. Schuurman, M. Duyvendak, and J. Zaagsma, "Deficiency of nitric oxide in polycation-induced airway hyperreactivity," British Journal of Pharmacology, vol. 126, no. 3, pp. 559-562, 1999.

[33] T. Yahata, Y. Nishimura, H. Maeda, and M. Yokoyama, "Modulation of airway responsiveness by anionic and cationic polyelectrolyte substances," European Journal of Pharmacology, vol. 434, no. 1-2, pp. 71-79, 2002.

[34] M. L. North et al., "Arginase in asthma - recent developments in animal and human studies," The Open Nitric Oxide Journal, vol. 2, pp. 20-36, 2010.

[35] G. Wu and S. M. Morris, "Arginine metabolism: nitric oxide and beyond," Biochemical Journal, vol. 336, no. 1, pp. 1-17, 1998.

[36] O. W. Griffith and D. J. Stuehr, "Nitric oxide synthases: properties and catalytic mechanism," Annual Review of Physiology, vol. 57, pp. 707-736, 1995.

[37] R. S. Reczkowski and D. E. Ash, "Rat liver arginase: Kinetic mechanism, alternate substrates, and inhibitors," Archives of Biochemistry and Biophysics, vol. 312, no. 1, pp. 31-37, 1994.

[38] H. Meurs, M. A. M. Hamer, S. Pethe, S. Vadon-Le Goff, J. L. Boucher, and J. Zaagsma, "Modulation of cholinergic airway reactivity and nitric oxide production by endogenous arginase activity," British Journal of Pharmacology, vol. 130, no. 8, pp. 1793-1798, 2000.

[39] M. Hecker, H. Nematollahi, C. Hey, R. Busse, and K. Racke, "Inhibition of arginase by $\mathrm{N}(\mathrm{G})$-hydroxy-L-arginine in alveolar macrophages: implications for the utilization of L-arginine for nitric oxide synthesis," FEBS Letters, vol. 359, no. 2-3, pp. 251-254, 1995.

[40] H. Maarsingh et al., "L-ornithine causes NO deficiency and airway hyperresponsiveness in perfused guinea pig tracheal preparations in vitro," Naunyn-Schmiedeberg's Archives of Pharmacology, vol. 375, p. 151, 2007.

[41] J. D. Cox, E. Cama, D. M. Colleluori et al., "Mechanistic and metabolic inferences from the binding of substrate analogues and products to arginase," Biochemistry, vol. 40, no. 9, pp. 2689-2701, 2001. 
[42] H. Meurs, S. McKay, H. Maarsingh et al., "Increased arginase activity underlies allergen-induced deficiency of cNos-derived nitric oxide and airway hyperresponsiveness," British Journal of Pharmacology, vol. 136, no. 3, pp. 391-398, 2002.

[43] P. Angeli, C. M. Prado, D. G. Xisto et al., "Effects of chronic L-NAME treatment lung tissue mechanics, eosinophilic and extracellular matrix responses induced by chronic pulmonary inflammation," American Journal of Physiology, vol. 294, no. 6, pp. L1197-L1205, 2008.

[44] M. Abe, Y. Hayashi, A. Murai et al., "Effects of inducible nitric oxide synthase inhibitors on asthma depending on administration schedule," Free Radical Biology and Medicine, vol. 40, no. 6, pp. 1083-1095, 2006.

[45] M. Endo, S. Oyadomari, Y. Terasaki et al., "Induction of arginase I and II in bleomycin-induced fibrosis of mouse lung," American Journal of Physiology, vol. 285, no. 2, pp. L313-L321, 2003.

[46] J. M. Bratt, L. M. Franzi, A. L. Linderholm, M. S. Last, N. J. Kenyon, and J. A. Last, "Arginase enzymes in isolated airways from normal and nitric oxide synthase 2-knockout mice exposed to ovalbumin," Toxicology and Applied Pharmacology, vol. 234, no. 3, pp. 273-280, 2009.

[47] H. Maarsingh, J. Leusink, I. S. T. Bos, J. Zaagsma, and H. Meurs, "Arginase strongly impairs neuronal nitric oxidemediated airway smooth muscle relaxation in allergic asthma," Respiratory Research, vol. 7, article 6, 2006.

[48] F. L. M. Ricciardolo, G. U. Di Maria, A. Mistretta, M. A. Sapienza, and P. Geppetti, "Impairment of bronchoprotection by nitric oxide in severe asthma," Lancet, vol. 350, no. 9087, pp. 1297-1298, 1997.

[49] H. Maarsingh, A. B. Zuidhof, I. S. T. Bos et al., "Arginase inhibition protects against allergen-induced airway obstruction, hyperresponsiveness, and inflammation," American Journal of Respiratory and Critical Care Medicine, vol. 178, no. 6, pp. 565-573, 2008.

[50] K. Ckless, A. Lampert, J. Reiss et al., "Inhibition of arginase activity enhances inflammation in mice with allergic airway disease, in association with increases in protein Snitrosylation and tyrosine nitration," Journal of Immunology, vol. 181, no. 6, pp. 4255-4264, 2008.

[51] A. K. Abbas, K. M. Murphy, and A. Sher, "Functional diversity of helper T lymphocytes," Nature, vol. 383, no. 6603, pp. 787-793, 1996.

[52] K. Asano, C. B. E. Chee, B. Gaston et al., "Constitutive and inducible nitric oxide synthase gene expression, regulation, and activity in human lung epithelial cells," Proceedings of the National Academy of Sciences of the United States of America, vol. 91, no. 21, pp. 10089-10093, 1994.

[53] K. H. Yip, Y. Huang, M. M. Y. Waye, and H. Y. A. Lau, "Induction of nitric oxide synthases in primary human cultured mast cells by IgE and proinflammatory cytokines," International Immunopharmacology, vol. 8, no. 5, pp. 764$768,2008$.

[54] I. M. Corraliza, G. Soler, K. Eichmann, and M. Modolell, "Arginase induction by suppressors of nitric oxide synthesis (IL-4, IL-10 and PGE) in murine bone-marrow-derived macrophages," Biochemical and Biophysical Research Communications, vol. 206, no. 2, pp. 667-673, 1995.

[55] M. Modolell, I. M. Corraliza, F. Link, G. Soler, and K. Eichmann, "Reciprocal regulation of the nitric oxide synthase-arginase balance in mouse bone marrow-derived macrophages by TH1 and TH2 cytokines," European Journal of Immunology, vol. 25, no. 4, pp. 1101-1104, 1995.
[56] A. Erdely, D. Kepka-Lenhart, M. Clark et al., "Inhibition of phosphodiesterase 4 amplifies cytokine-dependent induction of arginase in macrophages," American Journal of Physiology, vol. 290, no. 3, pp. L534-L539, 2006.

[57] H. Maarsingh, B. E. Bossenga, I. S. T. Bos, H. H. Volders, J. Zaagsma, and H. Meurs, "L-Arginine deficiency causes airway hyperresponsiveness after the late asthmatic reaction," European Respiratory Journal, vol. 34, no. 1, pp. 191-199, 2009.

[58] M. L. North, N. Khanna, P. A. Marsden, H. Grasemann, and J. A. Scott, "Functionally important role for arginase 1 in the airway hyperresponsiveness of asthma," American Journal of Physiology, vol. 296, no. 6, pp. L911-L920, 2009.

[59] N. Zimmermann, N. E. King, J. Laporte et al., "Dissection of experimental asthma with DNA microarray analysis identifies arginase in asthma pathogenesis," Journal of Clinical Investigation, vol. 111, no. 12, pp. 1863-1874, 2003.

[60] A. L. Greene, M. S. Rutherford, R. R. Regal et al., "Arginase activity differs with allergen in the effector phase of ovalbumin- versus trimellitic anhydride-induced asthma," Toxicological Sciences, vol. 88, no. 2, pp. 420-433, 2005.

[61] K. Takemoto, K. Ogino, M. Shibamori et al., "Transiently, paralleled upregulation of arginase and nitric oxide synthase and the effect of both enzymes on the pathology of asthma," American Journal of Physiology, vol. 293, no. 6, pp. L1419L1426, 2007.

[62] N. G. Sandler, M. M. Mentink-Kane, A. W. Cheever, and T. A. Wynn, "Global gene expression profiles during acute pathogen-induced pulmonary inflammation reveal divergent roles for Th1 and Th2 responses in tissue repair," Journal of Immunology, vol. 171, no. 7, pp. 3655-3667, 2003.

[63] M. Yang, D. Rangasamy, K. I. Matthaei et al., "Inhibition of arginase I activity by RNA interference attenuates IL-13induced airways hyperresponsiveness," Journal of Immunology, vol. 177, no. 8, pp. 5595-5603, 2006.

[64] T. Sharkhuu, K. I. Matthaei, E. Forbes et al., "Mechanism of interleukin-25 (IL-17E)-induced pulmonary inflammation and airways hyper-reactivity," Clinical and Experimental Allergy, vol. 36, no. 12, pp. 1575-1583, 2006.

[65] C. C. Lewis, J. Y. H. Yang, X. Huang et al., "Disease-specific gene expression profiling in multiple models of lung disease," American Journal of Respiratory and Critical Care Medicine, vol. 177, no. 4, pp. 376-387, 2008.

[66] S. A. Kharitonov, B. J. O’Connor, D. J. Evans, and P. J. Barnes, "Allergen-induced late asthmatic reactions are associated with elevation of exhaled nitric oxide," American Journal of Respiratory and Critical Care Medicine, vol. 151, no. 6, pp. 1894-1899, 1995.

[67] Z. Q. Yan, G. K. Hansson, B. E. Skoogh, and J. O. Lotvall, "Induction of nitric oxide synthase in a model of allergic occupational asthma," Allergy, vol. 50, no. 9, pp. 760-764, 1995.

[68] L. J. Dupont, F. Rochette, M. G. Demedts, and G. M. Verleden, "Exhaled nitric oxide correlates with airway hyperresponsiveness in steroid-naive patients with mild asthma," American Journal of Respiratory and Critical Care Medicine, vol. 157, no. 3, pp. 894-898, 1998.

[69] A. Jatakanon, S. Lim, S. A. Kharitonov, K. F. Chung, and P. J. Barnes, "Correlation between exhaled nitric oxide, sputum eosinophils, and methacholine responsiveness in patients with mild asthma," Thorax, vol. 53, no. 2, pp. 91-95, 1998.

[70] S. A. Kharitonov and P. J. Barnes, "Clinical aspects of exhaled nitric oxide," European Respiratory Journal, vol. 16, no. 4, pp. 781-792, 2000. 
[71] A. Jatakanon, S. Kharitonov, S. Lim, and P. J. Barnes, "Effect of differing doses of inhaled budesonide on markers of airway inflammation in patients with mild asthma," Thorax, vol. 54, no. 2, pp. 108-114, 1999.

[72] E. L. J. Van Rensen, K. C. M. Straathof, M. A. VeselicCharvat, A. H. Zwinderman, E. H. Bel, and P. J. Sterk, "Effect of inhaled steroids on airway hyperresponsiveness, sputum eosinophils, and exhaled nitric oxide levels in patients with asthma," Thorax, vol. 54, no. 5, pp. 403-408, 1999.

[73] J. Hjoberg, S. Shore, L. Kobzik et al., "Expression of nitric oxide synthase- 2 in the lungs decreases airway resistance and responsiveness," Journal of Applied Physiology, vol. 97, no. 1, pp. 249-259, 2004.

[74] G. Sadeghi-Hashin, G. Folkerts, P. A. J. Henricks et al., "Peroxynitrite induces airway hyperresponsiveness in guinea pigs in vitro and in vivo," American Journal of Respiratory and Critical Care Medicine, vol. 153, no. 5, pp. 1697-1701, 1996.

[75] H. Sugiura, M. Ichinose, T. Oyake et al., "Role of peroxynitrite in airway microvascular hyperpermeability during late allergic phase in guinea pigs," American Journal of Respiratory and Critical Care Medicine, vol. 160, no. 2, pp. 663-671, 1999.

[76] B. M. Fischer and J. A. Voynow, "Neutrophil elastase induces MUC5AC gene expression in airway epithelium via a pathway involving reactive oxygen species," American Journal of Respiratory Cell and Molecular Biology, vol. 26, no. 4, pp. 447-452, 2002.

[77] J. De Boer, H. Meurs, L. Flendrig, M. Koopal, and J. Zaagsma, "Role of nitric oxide and superoxide in allergen-induced airway hyperreactivity after the late asthmatic reaction in guinea-pigs," British Journal of Pharmacology, vol. 133, no. 8, pp. 1235-1242, 2001.

[78] D. Saleh, P. Ernst, S. Lim, P. J. Barnes, and A. Giaid, "Increased formation of the potent oxidant peroxynitrite in the airways of asthmatic patients is associated with induction of nitric oxide synthase: effect of inhaled glucocorticoid," FASEB Journal, vol. 12, no. 11, pp. 929-937, 1998.

[79] T. Hanazawa, S. A. Kharitonov, and P. J. Barnes, "Increased nitrotyrosine in exhaled breath condensate of patients with asthma," American Journal of Respiratory and Critical Care Medicine, vol. 162, no. 4, pp. 1273-1276, 2000.

[80] G. Sadeghi-Hashjin, G. Folkerts, P. A. J. Henricks, R. B. R. Muijsers, and F. P. Nijkamp, "Peroxynitrite in airway diseases," Clinical and Experimental Allergy, vol. 28, no. 12, pp. 1464-1473, 1998.

[81] M. G. Persson and L. E. Gustafsson, "Allergen-induced airway obstruction in guinea-pigs is associated with changes in nitric oxide levels in exhaled air," Acta Physiologica Scandinavica, vol. 149, no. 4, pp. 461-466, 1993.

[82] J. De Boer, H. Meurs, W. Coers et al., "Deficiency of nitric oxide in allergen-induced airway hyperreactivity to contractile agonists after the early asthmatic reaction: an ex vivo study," British Journal of Pharmacology, vol. 119, no. 6, pp. 1109-1116, 1996.

[83] M. Schuiling, A. B. Zuidhof, M. A. A. Bonouvrie, N. Venema, J. Zaagsma, and H. Meurs, "Role of nitric oxide in the development and partial reversal of allergen-induced airway hyperreactivity in conscious, unrestrained guineapigs," British Journal of Pharmacology, vol. 123, no. 7, pp. 1450-1456, 1998.

[84] Y. Xia, L. J. Roman, B. S. S. Masters, and J. L. Zweier, "Inducible nitric-oxide synthase generates superoxide from the reductase domain," Journal of Biological Chemistry, vol. 273, no. 35, pp. 22635-22639, 1998.
[85] Y. Xia and J. L. Zweier, "Direct measurement of nitric oxide generation from nitric oxide synthase," Proceedings of the National Academy of Sciences of the United States of America, vol. 94, no. 23, pp. 12705-12710, 1997.

[86] N. J. Kenyon, J. M. Bratt, A. L. Linderholm, M. S. Last, and J. A. Last, "Arginases I and II in lungs of ovalbumin-sensitized mice exposed to ovalbumin: sources and consequences," Toxicology and Applied Pharmacology, vol. 230, no. 3, pp. 269-275, 2008.

[87] H. Maarsingh et al., "Increased arginase activity underlies airway hyperresponsiveness in a guinea pig model of chronic allergic asthma," American Journal of Respiratory and Critical Care Medicine, vol. 175, p. A522, 2007.

[88] L. Kochański, S. Kossmann, E. Rogala, and J. Dwornicki, "Sputum arginase activity in bronchial asthma," Pneumonologia Polska, vol. 48, no. 5, pp. 329-332, 1980.

[89] H. Li, I. Romieu, J. J. Sienra-Monge et al., "Genetic polymorphisms in arginase I and II and childhood asthma and atopy," Journal of Allergy and Clinical Immunology, vol. 117, no. 1, pp. 119-126, 2006.

[90] C. R. Morris, M. Poljakovic, L. Lavrisha, L. Machado, F. A. Kuypers, and S. M. Morris, "Decreased arginine bioavailability and increased serum arginase activity in asthma," American Journal of Respiratory and Critical Care Medicine, vol. 170, no. 2, pp. 148-153, 2004.

[91] A. Lara, S. B. Khatri, Z. Wang et al., "Alterations of the arginine metabolome in asthma," American Journal of Respiratory and Critical Care Medicine, vol. 178, no. 7, pp. 673-681, 2008.

[92] M. Munder, F. Mollinedo, J. Calafat et al., "Arginase I is constitutively expressed in human granulocytes and participates in fungicidal activity," Blood, vol. 105, no. 6, pp. 2549-2556, 2005.

[93] S. Gordon, "Alternative activation of macrophages," Nature Reviews Immunology, vol. 3, no. 1, pp. 23-35, 2003.

[94] F. O. Martinez, L. Helming, and S. Gordon, "Alternative activation of macrophages: an immunologic functional perspective," Annual Review of Immunology, vol. 27, pp. 451483, 2009.

[95] M. Hesse, M. Modolell, A. C. La Flamme et al., "Differential regulation of nitric oxide synthase- 2 and arginase- 1 by type 1/type 2 cytokines in vivo: granulomatous pathology is shaped by the pattern of L-arginine metabolism," Journal of Immunology, vol. 167, no. 11, pp. 6533-6544, 2001.

[96] J. T. Pesce, T. R. Ramalingam, M. M. Mentink-Kane et al., "Arginase-1-expressing macrophages suppress Th2 cytokinedriven inflammation and fibrosis," PLoS Pathogens, vol. 5, no. 4, Article ID e1000371, 2009.

[97] K. A. Niese, A. R. Collier, A. R. Hajek et al., "Bone marrow cell derived arginase I is the major source of allergen-induced lung arginase but is not required for airway hyperresponsiveness, remodeling and lung inflammatory responses in mice," BMC Immunology, vol. 10, article no. 33, 2009.

[98] S. Wenzel and S. T. Holgate, "The mouse trap: it still yields few answers in asthma," American Journal of Respiratory and Critical Care Medicine, vol. 174, no. 11, pp. 1173-1176, 2006.

[99] R. Fattouh and M. Jordana, "TGF- $\beta$, eosinophils and IL13 in allergic airway remodeling: a critical appraisal with therapeutic considerations," Inflammation and AllergyDrug Targets, vol. 7, no. 4, pp. 224-236, 2008.

[100] A. L. Mora, E. Torres-González, M. Rojas et al., "Activation of alveolar macrophages via the alternative pathway in herpesvirus-induced lung fibrosis," American Journal of 
Respiratory Cell and Molecular Biology, vol. 35, no. 4, pp. 466473, 2006.

[101] H. Liu, P. Drew, A. C. Gaugler, Y. Cheng, and G. A. Visner, "Pirfenidone inhibits lung allograft fibrosis through L-arginine-arginase pathway," American Journal of Transplantation, vol. 5, no. 6, pp. 1256-1263, 2005.

[102] A. M. Pulichino, I. M. Wang, A. Caron et al., "Identification of transforming growth factor $\beta 1$-driven genetic programs of acute lung fibrosis," American Journal of Respiratory Cell and Molecular Biology, vol. 39, no. 3, pp. 324-336, 2008.

[103] C. R. Morris, "Mechanisms of vasculopathy in sickle cell disease and thalassemia," Hematology. American Society of Hematology. Education Program, pp. 177-185, 2008.

[104] N. J. Kenyon, K. Gohil, and J. A. Last, "Susceptibility to ovalbumin-induced airway inflammation and fibrosis in inducible nitric oxide synthetase-deficient mice: mechanisms and consequences," Toxicology and Applied Pharmacology, vol. 191, no. 1, pp. 2-11, 2003.

[105] A. M. Hamad, S. R. Johnson, and A. J. Knox, "Antiproliferative effects of NO and ANP in cultured human airway smooth muscle," American Journal of Physiology, vol. 277, no. 5 21-5, pp. L910-L918, 1999.

[106] A. M. Hamad and A. J. Knox, "Mechanisms mediating the antiproliferative effects of nitric oxide in cultured human airway smooth muscle cells," FEBS Letters, vol. 506, no. 2, pp. 91-96, 2001.

[107] H. J. Patel, M. G. Belvisi, L. E. Donnelly, M. H. Yacoub, K. F. Chung, and J. A. Mitchell, "Constitutive expressions of type I NOS in human airway smooth muscle cells: evidence for an antiproliferative role," FASEB Journal, vol. 13, no. 13, pp. 1810-1816, 1999.

[108] Y. Kizawa, N. Ohuchi, K. Saito, T. Kusama, and H. Murakami, "Effects of endothelin-1 and nitric oxide on proliferation of cultured guinea pig bronchial smooth muscle cells," Comparative Biochemistry and Physiology C, vol. 128, no. 4, pp. 495-501, 2001.

[109] J. Thyberg and B. B. Fredholm, "Modulation of arterial smooth muscle cells from contractile to synthetic phenotype requires induction of ornithine decarboxylase activity and polyamine synthesis," Experimental Cell Research, vol. 170, no. 1, pp. 153-159, 1987.

[110] J. Thyberg and B. B. Fredholm, "Induction of ornithine decarboxylase activity and putrescine synthesis in arterial smooth muscle cells stimulated with platelet-derived growth factor," Experimental Cell Research, vol. 170, no. 1, pp. 160169, 1987.

[111] W. Durante, L. Liao, K. J. Peyton, and A. I. Schafer, "Thrombin stimulates vascular smooth muscle cell polyamine synthesis by inducing cationic amino acid transporter and ornithine decarboxylase gene expression," Circulation Research, vol. 83, no. 2, pp. 217-223, 1998.

[112] W. Durante, L. Liao, S. V. Reyna, K. J. Peyton, and A. I. Schafer, "Transforming growth factor- $\beta$ stimulates Larginine transport and metabolism in vascular smooth muscle cells: role in polyamine and collagen synthesis," Circulation, vol. 103, no. 8, pp. 1121-1127, 2001.

[113] G. Wu, "Intestinal mucosal amino acid catabolism," Journal of Nutrition, vol. 128, no. 8, pp. 1249-1252, 1998.

[114] W. H. Waugh, C. W. Daeschner, B. A. Files, M. E. McConnell, and S. E. Strandjord, "Oral citrulline as arginine precursor may be beneficial in sickle cell disease: early phase two results," Journal of the National Medical Association, vol. 93, no. 10, pp. 363-371, 2001.
[115] C. Morris et al., "Metabolic fate of oral glutamine supplementation within plasma and erythrocytes of patients with sickle cell disease: preliminary pharmacokinetics results," Blood, vol. 116, abstract 1636, 2010.

[116] A. C. Koumbourlis, H. J. Zar, A. Hurlet-Jensen, and M. R. Goldberg, "Prevalence and reversibility of lower airway obstruction in children with sickle cell disease," Journal of Pediatrics, vol. 138, no. 2, pp. 188-192, 2001.

[117] J. H. Boyd, A. Moinuddin, R. C. Strunk, and M. R. DeBaun, "Asthma and acute chest in sickle-cell disease," Pediatric Pulmonology, vol. 38, no. 3, pp. 229-232, 2004.

[118] R. Bryant, "Asthma in the pediatric sickle cell patient with acute chest syndrome," Journal of Pediatric Health Care, vol. 19, no. 3, pp. 157-162, 2005.

[119] J. M. Knight-Madden, T. S. Forrester, N. A. Lewis, and A. Greenough, "Asthma in children with sickle cell disease and its association with acute chest syndrome," Thorax, vol. 60, no. 3, pp. 206-210, 2005.

[120] M. E. Nordness, J. Lynn, M. C. Zacharisen, P. J. Scott, and K. J. Kelly, "Asthma is a risk factor for acute chest syndrome and cerebral vascular accidents in children with sickle cell disease," Clinical and Molecular Allergy, vol. 3, article 2, 2005.

[121] J. H. Boyd, E. A. Macklin, R. C. Strunk, and M. R. DeBaun, "Asthma is associated with acute chest syndrome and pain in children with sickle cell anemia," Blood, vol. 108, no. 9, pp. 2923-2927, 2006.

[122] K. P. Sylvester, R. A. Patey, S. Broughton et al., "Temporal relationship of asthma to acute chest syndrome in sickle cell disease," Pediatric Pulmonology, vol. 42, no. 2, pp. 103-106, 2007.

[123] J. H. Boyd, E. A. Macklin, R. C. Strunk, and M. R. DeBaun, "Asthma is associated with increased mortality in individuals with sickle cell anemia," Haematologica, vol. 92, no. 8, pp. 1115-1118, 2007.

[124] R. W. Hagar, J. G. Michlitsch, J. Gardner, E. P. Vichinsky, and C. R. Morris, "Clinical differences between children and adults with pulmonary hypertension and sickle cell disease," British Journal of Haematology, vol. 140, no. 1, pp. 104-112, 2008.

[125] C. R. Morris, "Asthma management: reinventing the wheel in sickle cell disease," American Journal of Hematology, vol. 84, no. 4, pp. 234-241, 2009.

[126] C. R. Morris, "Role of arginase in sickle cell lung disease and hemolytic anemias," The Open Nitric Oxide Journal, vol. 2, pp. 41-54, 2010.

[127] C. R. Morris, G. J. Kato, M. Poljakovic et al., "Dysregulated arginine metabolism, hemolysis-associated pulmonary hypertension, and mortality in sickle cell disease," Journal of the American Medical Association, vol. 294, no. 1, pp. 81-90, 2005.

[128] C. R. Morris, "Hemolysis-associated pulmonary hypertension in sickle cell disease: global disruption of the argininenitric oxide pathway," Current Hypertension Reviews, vol. 3, no. 3, pp. 223-230, 2007.

[129] C. R. Morris, M. T. Gladwin, and G. J. Kato, "Nitric oxide and arginine dysregulation: a novel pathway to pulmonary hypertension in hemolytic disorders," Current Molecular Medicine, vol. 8, no. 7, pp. 620-632, 2008.

[130] C. R. Morris, F. A. Kuypers, G. J. Kato et al., "Hemolysisassociated pulmonary hypertension in thalassemia," Annals of the New York Academy of Sciences, vol. 1054, pp. 481-485, 2005. 
[131] C. R. Morris, E. Vichinsky, and S. T. Singer, "Pulmonary hypertension in thalassemia: association with hemolysis, arginine metabolism dysregulation and a hypercoaguable state," Advances in Pulmonary Hypertension, vol. 5, pp. 3138, 2007.

[132] C. R. Morris and E. P. Vichinsky, "Pulmonary hypertension in thalassemia," Annals of the New York Academy of Sciences, vol. 1202, pp. 205-213, 2010.

[133] H. Maarsingh, T. Pera, and H. Meurs, "Arginase and pulmonary diseases," Naunyn-Schmiedeberg's Archives of Pharmacology, vol. 378, no. 2, pp. 171-184, 2008.

[134] H. Maarsingh, J. Zaagsma, and H. Meurs, "Arginase: a key enzyme in the pathophysiology of allergic asthma opening novel therapeutic perspectives," British Journal of Pharmacology, vol. 158, no. 3, pp. 652-664, 2009.

[135] C. R. Morris, S. M. Morris, W. Hagar et al., "Arginine therapy: a new treatment for pulmonary hypertension in sickle cell disease?" American Journal of Respiratory and Critical Care Medicine, vol. 168, no. 1, pp. 63-69, 2003.

[136] C. R. Morris, "New strategies for the treatment of pulmonary hypertension in sickle cell disease: the rationale for arginine therapy," Treatments in Respiratory Medicine, vol. 5, no. 1, pp. 31-45, 2006.

[137] R. F. Machado and M. T. Gladwin, "Pulmonary hypertension in hemolytic disorders: pulmonary vascular disease: the global perspective," Chest, vol. 137, no. 6, pp. 30S-38S, 2010.

[138] C. R. Morris, "Decreased arginine bioavailability contributes to the pathogenesis of pulmonary artery hypertension," in Proceedings of the American College of Cardiology Annual Meeting, Orlando, Fla, USA, 2005.

[139] W. Xu, F. T. Kaneko, S. Zheng et al., "Increased arginase II and decreased NO synthesis in endothelial cells of patients with pulmonary arterial hypertension," FASEB Journal, vol. 18, no. 14, pp. 1746-1748, 2004.

[140] J. J. Field and M. R. DeBaun, "Asthma and sickle cell disease: two distinct diseases or part of the same process?" Hematology. American Society of Hematology. Education Program, pp. 45-53, 2009.

[141] O. Y. Ozbek, B. Malbora, N. Sen, A. C. Yazici, E. Ozyurek, and N. Ozbek, "Airway hyperreactivity detected by methacholine challenge in children with sickle cell disease," Pediatric Pulmonology, vol. 42, no. 12, pp. 1187-1192, 2007.

[142] M. A. Leong, C. Dampier, L. Varlotta, and J. L. Allen, "Airway hyperreactivity in children with sickle cell disease," Journal of Pediatrics, vol. 131, no. 2, pp. 278-285, 1997.

[143] J. J. Field et al., "Airway hyper-responsiveness in children with sickle cell anemia," Chest, vol. 139, no. 3, pp. 563-568, 2011.

[144] G. J. Kato, V. McGowan, R. F. Machado et al., "Lactate dehydrogenase as a biomarker of hemolysis-associated nitric oxide resistance, priapism, leg ulceration, pulmonary hypertension, and death in patients with sickle cell disease," Blood, vol. 107, no. 6, pp. 2279-2285, 2006.

[145] N. Sen, I. Kozanoglu, M. Karatasli, H. Ermis, C. Boga, and F. O. Eyuboglu, "Pulmonary function and airway hyperresponsiveness in adults with sickle cell disease," Lung, vol. 187, no. 3, pp. 195-200, 2009. 


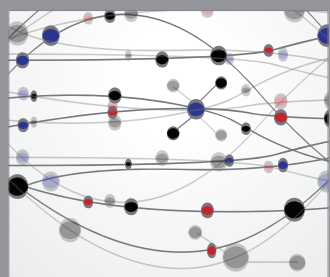

The Scientific World Journal
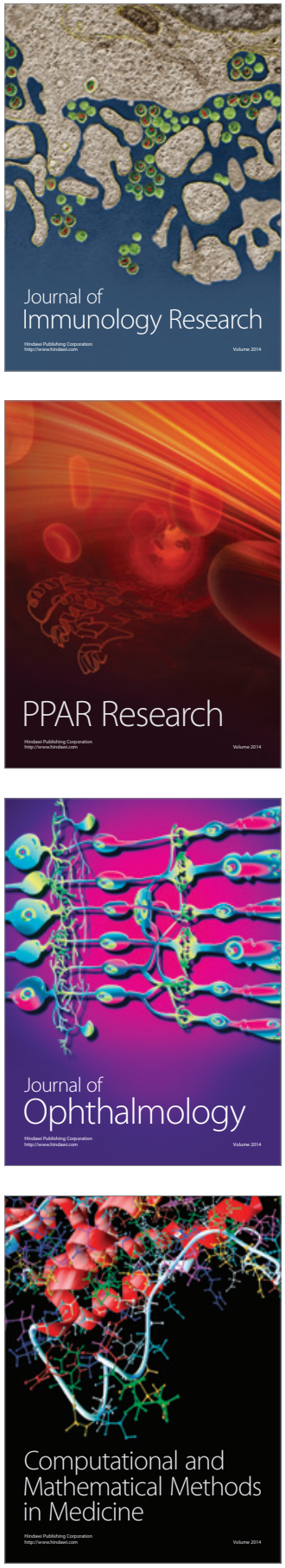

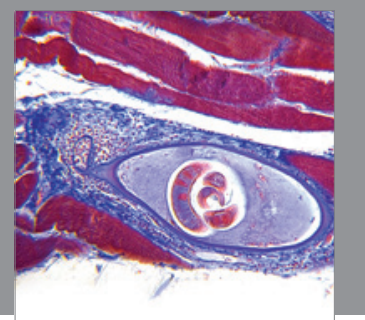

Gastroenterology

Research and Practice
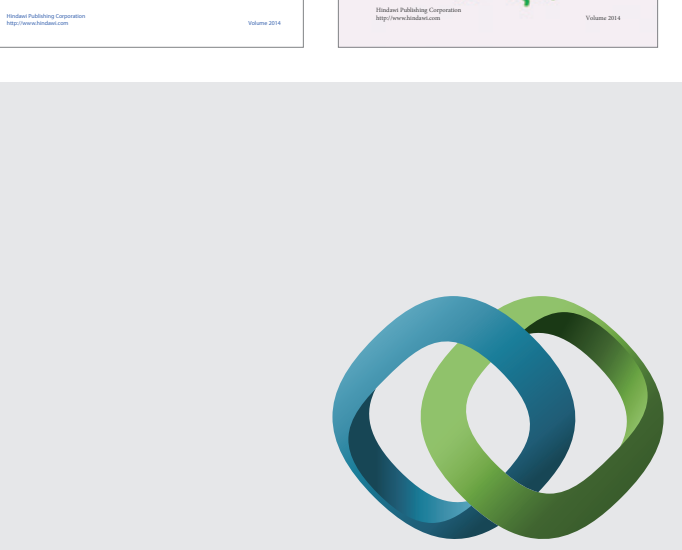

\section{Hindawi}

Submit your manuscripts at

http://www.hindawi.com
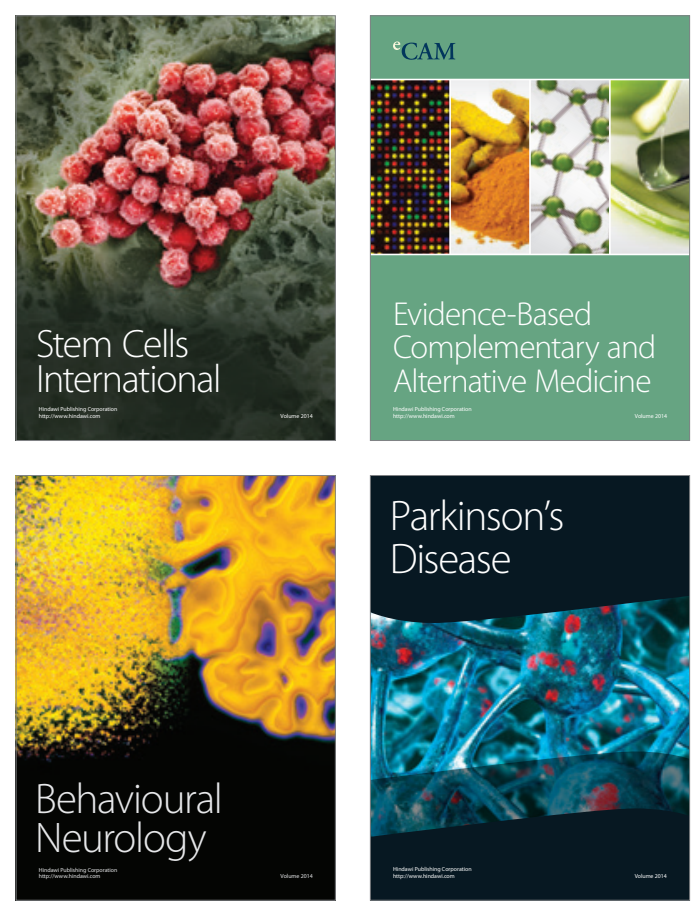

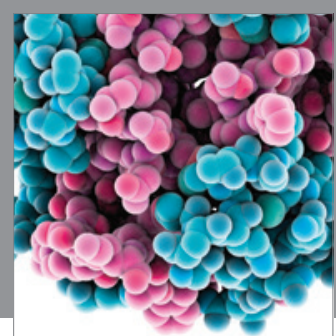

Journal of
Diabetes Research

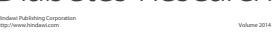

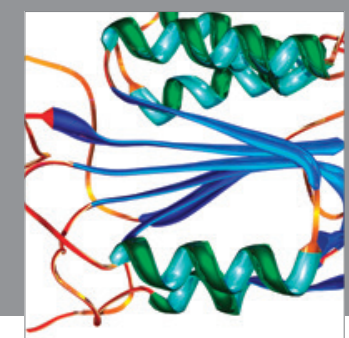

Disease Markers
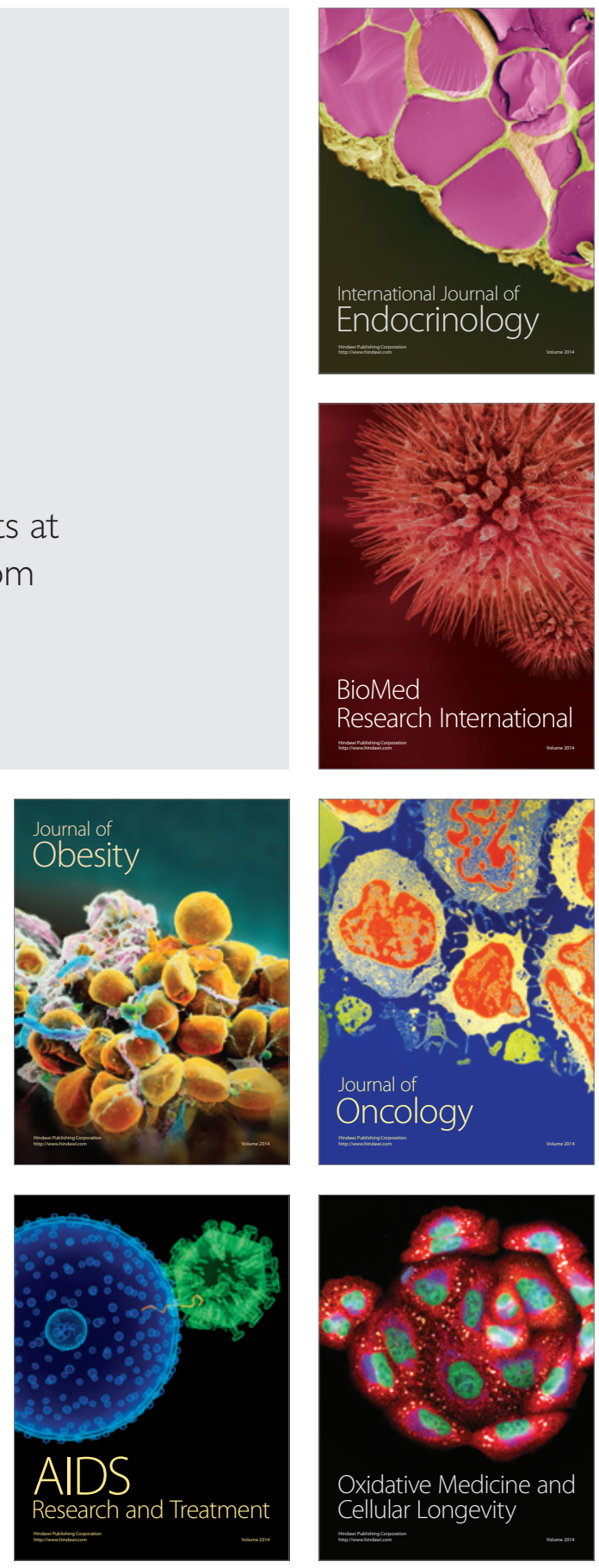